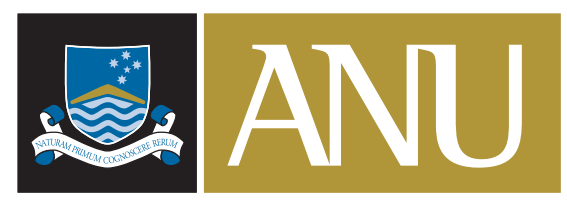

AUSTRALIA-JAPAN RESEARCH CENTRE

ANU COLLEGE OF ASIA \& THE PACIFIC

CRAWFORD SCHOOL OF ECONOMICS AND GOVERNMENT

\title{
HOW DOES FINANCIAL SYSTEM EFFICIENCY AFFECT THE GROWTH IMPACT OF FDI IN CHINA?
}

Ying Xu

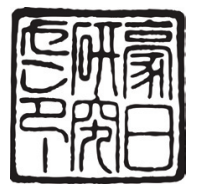

ASIA PACIFIC ECONOMIC PAPERS

No. 383, 2009 



\title{
ASIA PACIFIC ECONOMIC PAPER N0. 383
}

2009

\section{How does financial system efficiency affect the growth impact of FDI in China?}

\author{
Ying $\mathrm{Xu}^{u^{*}}$
}

AUSTRALIA-JAPAN RESEARCH CENTRE CRAWFORD SCHOOL OF ECONOMICS \& GOVERNMENT

ANU COLLEGE OF ASIA AND THE PACIFIC 
(C) YING XU, 2009.

This work is copyright. Apart from those uses which may be permitted under the Copyright Act 1968 as amended, no part may be reproduced by any process without written permission.

Asia Pacific Economic Papers are published under the direction of the Editorial Committee of the Australia-Japan Research Centre (AJRC). Members of the Editorial Committee are:

Professor Jenny Corbett

Executive Director

Australia-Japan Research Centre

The Australian National University, Canberra

Professor Emeritus Peter Drysdale

Crawford School of Economics and Government

The Australian National University, Canberra

Professor Christopher Findlay

Professor of Economics

University of Adelaide

Adelaide, South Australia

Professor Stuart Harris

Department of International Relations

The Australian National University, Canberra

Dr Kazuki Onji

Crawford School of Economics and Government

The Australian National University, Canberra

Papers submitted for publication in this series are subject to double-blind external review by two referees. The views expressed in APEPs are those of the individual authors and do not represent the views of the Australia-Japan Research Centre, the Crawford School, or the institutions to which authors are attached.

The Australia-Japan Research Centre is part of the Crawford School of Economics and Government, The Australian National University, Canberra.

ISSN 07288409

ISBN 9780864133380

Australia-Japan Research Centre

Crawford School of Economics and Government

The Australian National University

CAnberra ACT 0200

Telephone: (61 2) 61253780

FACSIMILE: (61 2) 61258448

E-MAIL: AJRC@ANU.EDU.AU

URL: HTTP://WWW.CRAWFORD.ANU.EDU.AU 


\section{How Does Financial System Efficiency Affect THE GROWTH IMPACT OF FDI IN CHINA?}

In spite of being the second largest recipient of FDI in the world, China shows limited evidence of considerable FDI benefits on growth (Fan and Hu 2007; Luo 2007; Ran et al. 2007). Motivated by Alfaro et al.'s (2003) model, this study tests whether poor financial market development might be responsible for the relatively low benefits of FDI on growth in China. We apply Blundell-Bond system GMM estimators to a panel of Chinese provinces. Our results indicate that poor financial intermediation does indeed limit the transmission of FDI benefits within the Chinese economy. Moreover, the study reveals preliminary evidence that banks' credits to unproductive State Owned Enterprises (SOEs) constitute poor financial intermediation with negative growth implications. In contrast, credits to small private enterprises are associated with a positive impact of FDI on growth.

JEL classification: N25, F21, F23, O11, O16

Key words: foreign direct investment, FDI spill-overs, financial development, credit misallocation, economic growth, China *Crawford School of Economics and Government, Australian National University 


\section{Introduction}

China stands as the world's second largest recipient of Foreign Direct Investment (FDI) inflows since 2006. Actual FDI inflows into China over 2007-08 were USD 112 billion. However a top-rank FDI recipient country China may be, its utilisation of FDI is less impressive. The empirical evidence of FDI-growth linkage in China is ambiguous. Some studies suggest positive effects of FDI on growth (Berthelemy and Demurger 2000; Yao 2006), whereas others find insignificant relationship between FDI and growth (Luo 2007; Ran et al. 2007). Laurenceson and Tang (2007)'s review of the empirical evidence of FDI-growth nexus suggests that FDI benefits in China are much smaller than expected with many strong positive results largely due to the failure to address serious econometric issues. $^{2}$ It is puzzling that a large volume of FDI delivers small impact on China. To explain the puzzle, many scholars suggest that FDI benefits are conditioned on host countries' local conditions and underline regional disparity, infrastructure quality, and local firms' learning ability being such conditions restraining FDI benefits in China (Luo 2007; Fan and Hu 2007; Ran et al. 2007). These are standard 'local absorptive capacities' prescriptions (BlomstrÖm and Kokko 1998).

This paper provides an alternative perspective to address the weak FDI-growth relationship found in China. Inspired by Alfaro et al.'s (2003) model and the understanding of the dilemma of Chinese financia systems, the study examines the role of the financial system in the FDI-growth linkage and reveals how financial market conditions could influence FDI benefits in China. In Alfaro et al.'s model, FDI contributes growth via spill-over effects on the productivity of domestic entrepreneurs. The number of domestic entrepreneurs able to operate (and therefore take advantage of the spill-overs from FDI) depends on the availability of credit and thus on the efficiency of the domestic financial system. A detailed review of the financial system development in China depicts an inefficient financial system in terms of credit allocation. Poor financial intermediation taking the form of credit misallocation remains dominant practice in the Chinese banking system despite rapid expansion of the banking sector and the government's continuing efforts on financial reforms. Hence, this observation supports the hypothesis that poor financial market development might be responsible for the low benefits of FDI in China.

The empirical analysis is characterised by several features. First, the study employs a unique province-level panel data-set compiled by the author. One of the major data limitations associated with most of the existing finance-growth studies in China is the absence of private credit data (Hao 2006), because such data are not available and in many cases nonexistent at the provincial level. However, data on short-term credits to individual private enterprises, to township and village enterprises, and to foreign-owned enterprises 
are reported in many provincial statistical yearbooks. They represent the main groups of recipients of the private credits issued by the financial institutions in China. So the dataset includes the three sub-groups of private credits to proxy private credits and therefore provides some suggestive insights on the role of private credits in the link between FDI and growth. Second, the analysis is carried out within the framework of an augmented Solow growth model. This is a widely-used framework and has demonstrated strong explanatory power of growth patterns across countries (Mankiw et al. 1992; Caselli et al. 1996; Benhabib and Spiegel 2000). Furthermore it is more relevant in a single-country case like this since an identical aggregate production is a more realistic assumption for provinces in a country than for countries in the world. Third, Blundell-Bond system GMM estimators are employed to estimate the dynamic panel model. Facilitated by the techniques developed by Roodman (2006 and 2008), system GMM estimation provides the most updated econometric methodology capable of generating consistent estimators in the presence of endogeneity and omitted variables, which are common problems associated with the growth model that is estimated in this study.

The key finding of the study is that financial development plays an important role in actualizing FDI benefits in China. Poor financial intermediation is found to have offset FDI benefits. When this financial market detrimental influence is taken into account, the FDI impacts on growth turn significantly positive. The second set of results provide preliminary evidence that helps distinguish productive credits - an indicator of good financial intermediation - from unproductive credits - an indicator of poor financial intermediation. Credits to small private enterprises make up the most productive credit category. They promote growth as well as magnify FDI benefits. Credits to SOEs constitute the unproductive credit group because they constrain growth and at the same time offset potential FDI benefits in China.

The paper is structured as follows. Section 2 introduces the theoretical model proposed by Alfaro et al. (2003), followed by a review of the financial system in China highlighting its major problem of credit misallocation in Section 3. Section 4 explains the empirical framework of this study, which is an augmented Solow growth model, estimated by system GMM estimation methodology. Section 5 presents the results and discusses their implications. The final section concludes with recommendations on FDI policies and priorities for financial reform in China.

\section{Theoretical framework}

The Alfaro et al. model provides a theoretical framework for understanding the interactive relationship between local financial markets and FDI benefits. It proposes the key hypotheses 
for the empirical examination in this paper. This section presents the main assumptions and intuition of the model. A detailed review is included in the appendix.

The model assumes a small open economy consisting of two sectors - the foreign production sector and the domestic production sector. A continuum of agents indexed by their levels of ability can either work for the foreign company or become entrepreneurs and undertake entrepreneur activities which are subject to a fixed cost. Efficient financial markets are characterised by ease of access to credit by capable entrepreneurs. Such a system allows more entrepreneurs to take advantage of benefits from FDI and magnifies the effects of FDI. In contrast, an inefficient financial system fails in serving the financial needs of potential entrepreneurs. As a result, entrepreneurship is badly nurtured and fewer entrepreneurs can survive to benefit from FDI. FDI effects are diminished.

The Alfaro et al. model provides a good framework for understanding the impact of financial markets on FDI benefits. Cross-country analysis has shown support for its prediction on a sample of 71 countries excluding transition economies (Alfaro et al. 2004). ${ }^{3}$ However, the current study intends to apply the model to a transition economy. Some modifications become essential due to special characteristics associated with these transitional financial systems. Two important modifications are required in the Chinese context. The first modification is related to the indicator of financial market efficiency. The Alfaro model adopts the traditional indicator - interest rate differentials, so a lower interest rate difference indicates a higher efficiency level and vice versa. However, data of interest rate differentials are not available at the provincial level. More importantly, as interest rates are partially controlled in China and allowed to fluctuate within a band set by the authorities, the interest rate differential is not as indicative a measure of financial market efficiency in China as it is in free market economies. Rather, actual loans extended are a more direct measure of the scale of financial intermediation and therefore used in this study.

Second, loans to different types of domestic enterprises are expected to have different implications for FDI benefits in China. Private enterprises are the dynamic part of the economy. They are motivated by market incentives and often quick to learn new technologies to compete for survival (Garnaut et al. 2001). Hence, private enterprises are expected to behave in consistent with the assumption of the model, so more credits to the private enterprises is an indication of good financial intermediation. However, state-owned enterprises (SOEs) as a whole constitute a relative unproductive part of the economy. In many studies such as Guariglia and Poncet (2007), credits to SOEs are considered as an indicator of poor financial intermediation in China. The next section provides a detailed account of why this is the case in China. 


\section{Financial intermediation in China}

The theoretical model highlights the important role of good financial intermediation in absorbing FDI benefits in a host economy. However, China's financial system overall offers an example of what constitutes poor financial intermediation. This section examines what form poor financial intermediation takes in China, why it exists, and how it has harmed the well-being of the real economy, including the benefits of FDI.

Undoubtedly, China's financial system has been growing rapidly after China opened up its economy in the late 1970s. Financial indicators show a high level of financial depth. China's financial stock (including equity, corporate debt, government debt, and bank deposits) grew from 117 per cent of GDP in 1994 to 221 per cent of GDP at the year end 2004, far exceeding those of other countries at similar levels of income per capita such as India and Indonesia (MGI 2006).

Despite rapid growth, China's financial system continues to bear the problem of credit misallocation, which is a direct result of poor financial intermediation. A further consequence of it is that the bulk of financial resources are directed to unproductive stateowned enterprises (Table 1) while better private enterprises deprived of external funding. As a result, the private credit ratio is unusually low. ${ }^{4}$ In 1999, it ranked China 63rd in the lowest quartile of a sample of 78 countries in the world (Boyreau-Bebray 2003). In that year, the private sector accounted for only one per cent of bank lending (IFC 1999). Over the past decade, credits to private companies have grown, but the speed has been rather modest.

Table 1 Performance of top 500 Chinese enterprises in 2007, by ownership (per cent)

\begin{tabular}{lccc}
\hline Ownership & Share of assets in total & Share of profits in total & Return on assets \\
\hline State & 93.6 & 87.9 & 1.4 \\
Collective & 4.2 & 2.2 & 0.8 \\
Private & 1.7 & 7.1 & 6.1 \\
Foreign & 0.5 & 2.8 & 8.5
\end{tabular}

Source: A report on the Development of China's Enterprises 2007, Enterprise Management Publishing House, Beijing, Chapter 12, p.88.

Private credits are constrained because state owned enterprises receive most of the funding from the financial system (Figure 1). In 2003, wholly state-owned enterprises absorbed 35 per cent of nonagricultural commercial bank loans. Enterprises with partial state ownership accounted for another 38 percent of outstanding credits. In total, despite producing less than half of the GDP, the state economy took up 73 per cent of credits. In 
contrast, the most productive private portion of the economy (including foreign firms) produced 52 per cent of GDP but received only 27 per cent of bank loans outstanding (MGI 2006). The statistics in Figure 1 show a skewed distribution of bank loans favouring the idle part of the economy, begging the question of how these lending decisions were made.

It appears that firm performance or project profitability is not a major concern for credit officers in China though it should be for loans to be productive. Other factors help them make decisions to lend to unprofitable state-owned enterprises. One major factor is government intervention, which is influential because financial intermediation in China is mostly bank-based and the commercial banking sector is dominated by state owned commercial banks under state control. The four biggest state-owned commercial banks together account for two-thirds of financial system assets.

Figure 1 Comparison of GDP and corporate bank loans outstanding, 2003

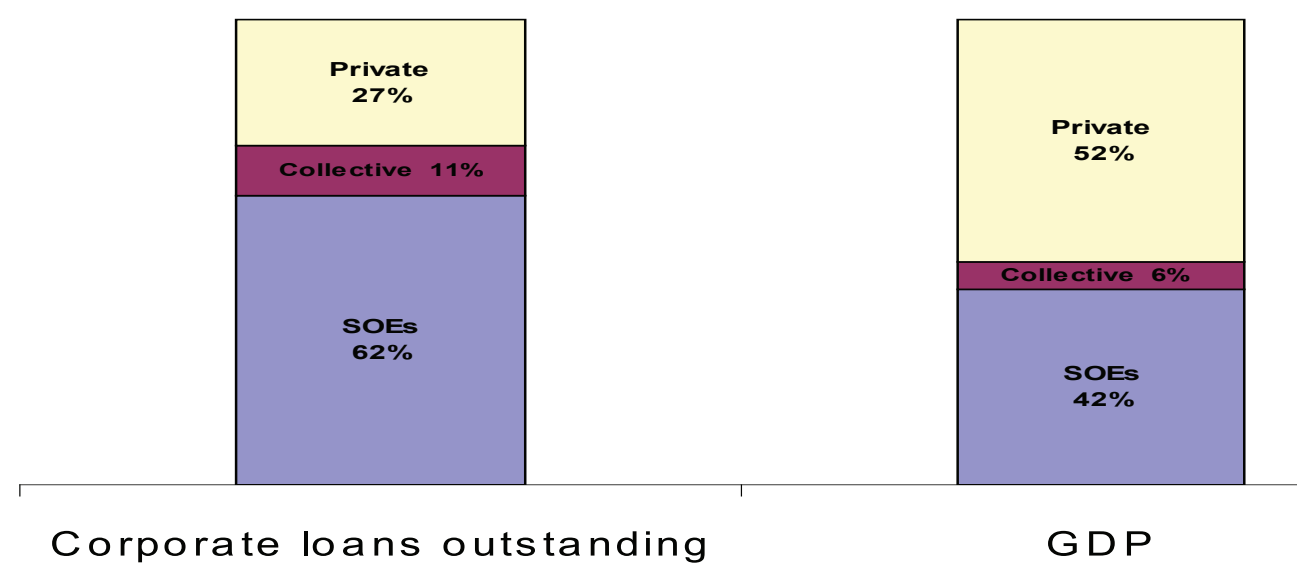

Notes:

1. State-owned enterprises or SOEs include wholly state-owned and shareholding enterprises. Most of the shareholding enterprises are partly state owned. Some are state controlled, some are not; Collective enterprises are owned by the population. Many run like private enterprises, but some are effectively controlled by local political interests; Private enterprises include local privately owned enterprises, foreign joint ventures, and wholly owned foreign enterprises.

2. Breakdown of industrial value-added by ownership type, 2003 , as determined by the Organisation for Economic Cooperation and Development.

3. Total corporate and government bank lending are based on a survey on commercial bank new loans conducted in 2002 by the People's Bank of China, which is the most recent publicly available data on lending by company type.

Source: OECD; PBOC; McKinsey Global Institute analysis (MGI 2006) 
Scholars observe two types of government intervention existing - 'ex ante intervention' and 'ex post intervention' (Lu et al. 2005). Before the lending decision is made, government intervention takes the form of 'policy lending' ${ }^{6}$ For example, the central government sometimes encourages banks to extend credit beyond the prudential level to achieve a targeted growth rate. Local governments press banks to lend to loss-making SOEs in order to avoid rising unemployment. In this way, political concerns outweigh economic fundamentals, which lead to many decisions of misallocation of the funds. Ex post intervention occurs after the lending decision is made. The government intervenes in the credit markets by bailing out troubled SOEs. Acknowledging the implicit government guarantee, state-owned banks are willing to lend to state-owned enterprises because loans to SOEs seem to be 'safer' (MGI 2006).

Without government protection, private enterprises are discriminated against in accessing bank credit. Before the end of the 1990s, this discrimination was legitimate because the private sector was not acknowledged as an integral part of the economy. After the system was liberalised, discrimination took a different form. Two surveys undertaken by the People's Bank of China (ACFB 2003) show banks in China are more likely to discriminate the borrowers by size rather than ownership, probably due to the fact that loan decisions are on the basis of collateral (Cheng and Degryse 2006). The average size of private enterprises is unusually small compared to state-owned enterprises (Huang 2003). This is mainly due to the fact that they lack the financial support to grow in the first place. However, because of the small size, they are again denied formal financial resources from the banking system and have to rely primarily on internal sources such as family savings, retained earnings and sometime even underground 'banks' for start-up capital and subsequent investment, which are an expensive and inefficient way of financing (IFC 2000).

That banks lend little to private enterprises and small firms also reflects institutional deficiencies. The MGI (2006) report reveals that most Chinese banks, including both large state-owned banks and small city and rural cooperatives, often lack the skills and tools to assess their credit and price loans. Moreover, hampered by the unreliability of financial reports of private companies and the insufficient legal enforcement of contracts, banks generally consider private lending 'too risky' and thus hesitate to extend loans to the private sector.

Misallocation of credits inflicts significant costs on many parts of the Chinese economy. An immediate cost is on the banking sector itself. Financial resources mobilised to the inefficient SOE sector over years have accumulated a large number of non-performing loans (NPL) for banks, which is a good indicator of the size of the cost of credit misallocation. By 2001, 31 per cent of loan balances of large commercial banks were categorised as NPLs. 
The number was reduced to 10 per cent in 2005, but can be almost entirely explained by the government's recapitalisation program through transferring the NPLs to state asset management companies (Podpiera 2006).

On the other hand, hefty loans to SOEs can not save poorly managed SOEs from failing. Rather they contribute to the soft-budget problem of SOEs and actually delay SOE reforms from taking effect. The overall productivity of the economy is lowered by allocating a disproportionate share of credit to the unproductive state sector.

Another important but often ignored category of cost is the opportunity costs of the misallocation of capital. If given easy access to the credit market and adequate financial support, the productive private sector could have generated more output. This could be realised by more private entrepreneurs starting up their businesses and more small private firms developing into larger competitive firms employing economies of scale.

A further implication is that FDI benefits would have been larger and more explicit if more loans were extended to the productive private sector. As the theoretical model shows, FDI benefits in a host country rely on a financial system that supports the development of local enterprises to absorb the benefits. However, it is clear from the review that financial intermediaries in China favour the SOE sector over the private sector and allow a disproportionate share of capital to flow into unproductive SOEs. Because of the almost unconditional support that SOEs receive from the state-owned banks, they have little motive to learn lessons from FDI that would help them to increase productivity and compete with the dynamic private sector. Rather, they are inclined to increase the production scale and employment to satisfy the government's concerns. However, the private sector is willing to learn and potentially able to absorb the benefits but deprived of the opportunity. This credit misallocation imposes a large cost to the economy and may explain the paradox of large FDI inflow but little FDI benefits in China, a proposition that the study intends to test in the following section.

\section{Empirical Framework}

This section constructs an empirical framework to examine the effects of financial sector development on FDI benefits in China. The two components of the framework are: an empirical model specification based on Mankiw, Romer and Weil (1992), and a dynamic panel model estimated by the system GMM estimation method.

\section{Model Specification}

As the central prediction of the theoretical model is that improvements in financial intermediation increase output by increasing the marginal product of FDI (Appendix), Alfaro 
et al. (2003) suggest that it is more relevant to observe the transitional growth effect in applying their model to data. This paper adopts Mankiw et al.'s (1992) model specification to capture the effects of financial markets on FDI benefits in terms of growth. This specification has been extensively tested in many growth studies and shows excellent description of cross-country data (Caselli et al. 1996; Benhabib and Spiegel 2000) as well as cross-province data in China (Hao 2006; Guariglia and Poncet 2007).

For a panel data-set across Chinese provinces, the baseline model takes the form:

$$
\begin{array}{r}
\ln \left(y_{i, t}\right)-\ln \left(y_{i, t-1}\right)=\beta \ln \left(y_{i, t-1}\right)+W_{i, t-1}{ }^{\prime} \delta+\eta_{i}+\xi_{t}+\varepsilon_{i, t} \\
(i=1, \ldots, N \text { and } t=2, \ldots, T)
\end{array}
$$

The growth of income per capita in province $i, \ln \left(y_{i, t}\right)-\ln \left(y_{i, t-1}\right)$, is a function of the province's initial level of income $\ln \left(y_{i, t-1}\right)$ and the determinants of its steady-state $W_{i, t-1}$. Fixed effects across provinces and time are taken into account and denoted by $\eta_{i}$ and $\xi_{t}$ respectively. $\varepsilon_{i, t}$ is the i.i.d. idiosyncratic error term.

Steady-state determinants $W_{i, t-1}$ include three groups of variables and values of the initial period are used as proxies. ${ }^{8}$ The first group is a group of variables used in the augmented Solow model, including population growth, saving rate and human capital. They are measured by the growth rate of working-age population, the share of investment in GDP including private investment and government investment, and the share of population holding tertiary-level qualifications respectively. Government investment or expenditure is also considered as an indicator of government size. The second group contains two policy variables, identified in the literature as important correlates of growth in the Chinese context. ${ }^{9}$ They are share of state entities in total investment as an indicator of the size of the state sector and trade volume to capture the degree of economic openness.

The model is extended by adding key variables of the analysis: FDI and local financial market indicators and their interactions. FDI is measured by total FDI inflows. Financial indicators include total loans and total deposits and three categories of private credits, including credits to individual enterprises, to township and village enterprises, and to foreign-owned enterprises.

A key issue relating to the model specification is whether and how to take ratios for the variables in level terms such as trade, FDI and financial market indicators. Traditionally, if the dependent variable is in ratios and so are most of the explanatory variables, it is optimal to transform the explanatory variables in levels into ratios to keep consistency (Firebaugh and Gibbs 1985). Otherwise, standard errors would rise and coefficients of these variables would become inefficient. Moreover, GDP ratios are often taken for endogenous variables such as trade and FDI as a standard way to neutralize the effect of economy size. These 
are valid because coefficients associated with these variables remain unchanged when the variables are in logarithmic form.

However, two problems arise on taking GDP ratios when the interaction terms are included in the model as in this study. First, the coefficients of the ratios are no longer the same as those of the levels for variables involved in the interaction terms and the interaction terms themselves. Some simple algebra illustrates this. ${ }^{10}$ Second, if interpreting the variables in the GDP ratios as they are, their meanings and the implications of the coefficients diverge from those implied in the theoretical model. For example, the FDI/GDP ratio is more of a measurement of FDI intensity. Thus the effect of FDI/GDP ratio on GDP per capita is different from the impact of FDI inflows on GDP, though the latter is more relevant to the theoretical model.

The study adopts per capita ratios as a remedy to tackle these two issues. First, per capita ratios are consistent with the dependent variable which is GDP per capita. Second, as a result of the consistency, these variables share the same interpretation as their level counterparts. Concerns about endogeneity will be formally addressed by the GMM methodology. All the monetary values are normalised to constant prices (2000) by provincial GDP deflators before taking per capita ratios. In some cases, such as trade and FDI inflow values, which are in US dollars, are first converted to local prices before normalisation. ${ }^{11}$

The analysis is undertaken in two steps. First a baseline regression is employed to examine the individual effects of FDI and the financial system on growth,

$$
\ln \left(y_{i, t}\right)=(1+\beta) \ln \left(y_{i, t-1}\right)+W_{i, t-1} ' \delta+\lambda \ln f d i_{i, t-1}+\gamma \ln f i n_{i, t-1}+\eta_{i}+\xi_{t}+\varepsilon_{i, t},
$$

Then, in an elaborate regression, FDI finance interaction term is added to assess the role of local financial sector development on FDI's impact on growth,

$$
\begin{aligned}
\ln \left(y_{i, t}\right)=(1+\tilde{\beta}) & \ln \left(y_{i, t-1}\right)+W_{i, t-1} ' \tilde{\delta}+\tilde{\lambda} \ln f d i_{i, t-1}+\tilde{\gamma} \ln f i n_{i, t-1} \\
& +\tilde{\phi}\left(\ln f d i_{i, t-1} \times \ln f i n_{i, t-1}\right)+\tilde{\eta}_{i}+\tilde{\xi}_{t}+\tilde{\varepsilon}_{i, t},
\end{aligned}
$$

A positive $\tilde{\phi}$ suggests that an improvement in financial efficiency leads to greater FDI effects on growth, whereas a negative $\tilde{\phi}$ indicates an increase in financial inefficiency reduces FDI benefits.

\section{GMM Estimation}

The empirical model shows several notable features. First, it has a dynamic structure and is a dynamic panel model. Due to the 'dynamic panel bias' exposed by Nickell $(1981)^{12}$, the classic OLS estimators in equation (2) are biased in the presence of individual fixed 
effects and the traditional Within-Group estimators are biased in short panels. ${ }^{13}$ Second, many variables involved in the model, such as investment, education, and trade, are wellknown endogenous variables and are usually persistent series. Finally, the issue of omitted variables is common problem associated with the empirical growth model, considering the large number of potential factors that might influence economic growth.

Arellano-Bond GMM Difference estimation method (Arellano and Bond 1991) and Blundell-Bond GMM System estimation method (Blundell and Bond 1998) ${ }^{14}$ are two of the most advanced and updated methods capable of addressing the issues of endogeneity issue and omitted variable and, most importantly, they confer unbiased and consistent estimators under these circumstances. However, Blundell and Bond (1998) find that Difference GMM estimators have poor finite sample properties and are subject to a large-downward finite-sample bias. Given a finite sample and a short panel data-set with persistent time-series, this study employs System GMM estimators as they show superior functionality in overcoming the shortcomings of Difference GMM counterparts.

The GMM approach, Difference GMM or System GMM, is an extension of generalised-method-of-moment approach integrating instrumental variables. The basic idea is to take first differences to remove unobserved time-invariant individual fixed effects, and then instrument the right-hand-side lagged dependent variables in the first-differenced equations using levels of the series lagged two periods or more. This is the difference GMM. The system GMM approach adds equations of levels to equations of differences (in Difference GMM) and thus estimates a system of equations. Instruments used in the levels equations are lagged first-differences of the series (Bond et al. 2001). All the instruments are only valid with certain conditions attached and these are explained in the illustration below, based on (Arellano and Bond 1991; Blundell and Bond 1998; Bond et al. 2001).

Recall the base line model (2) but in a simpler form,

$$
y_{i, t}=(1+\beta) y_{i, t-1}+W_{i, t-1}^{\prime} \delta+\eta_{i}+\xi_{t}+\varepsilon_{i, t}
$$

First-difference to remove the time-invariant fixed effects $\eta_{i}$

$y_{i, t}-y_{i, t-1}=(1+\beta)\left(y_{i, t-1}-y_{i, t-2}\right)+\left(W_{i, t-1}-W_{i, t-2}\right)^{\prime} \delta+\left(\xi_{t}-\xi_{t-1}\right)+\left(\varepsilon_{i, t}-\varepsilon_{i, t-1}\right)$,

$y_{i, t-2}$ and deeper lags of $y_{i, t}$ are qualified instruments for $\left(y_{i, t-1}-y_{i, t-2}\right)$ under the condition of no second order serial correlation in the idiosyncratic error term $\varepsilon_{i, t}$. This applies to instruments of endogenous explanatory variables. Exogenous explanatory variables employ standard instruments. Hence, the vectors of explanatory variables $w_{i, t-1}$ are categorised into three groups - endogenous $w_{i, t-1}^{\text {endo }}$, predetermined $w_{i, t-1}^{\text {pred }}$, and exogenous $w_{i, t-1}^{\text {exog }}$ ${ }^{15}$, moment conditions applying for $\left(y_{i, t-1}-y_{i, t-2}\right)$ and each group of $w_{i, t-1}-w_{i, t-2}$ in 
the first-difference equations are therefore,

$$
\begin{array}{ll}
E\left[y_{i, t-s}\left(\varepsilon_{i, t}-\varepsilon_{i, t-1}\right)\right]=0 & \text { for } s \geq 2 ; t=3, \ldots, T \\
E\left[W_{i, t-s}^{\text {endo }}\left(\varepsilon_{i, t}-\varepsilon_{i, t-1}\right)\right]=0 & \text { for } s \geq 2 ; t=3, \ldots, T \\
E\left[W_{i, t-s}^{\text {pred }}\left(\varepsilon_{i, t}-\varepsilon_{i, t-1}\right)\right]=0 & \text { for } s \geq 1 ; t=2, \ldots, T \\
E\left[W_{i, t}^{\text {exgo }}\left(\varepsilon_{i, t}-\varepsilon_{i, t-1}\right)\right]=0 & \text { for } t=1, \ldots, T
\end{array}
$$

System GMM estimators employs additional moment conditions for the level equations with 'the initial conditions' satisfied. ${ }^{16}$ The moment condition for $y_{i, t-1}$ is, $E\left[\left(y_{i, t-s}-y_{i, t-s-1}\right)\left(\eta_{i}+\varepsilon_{i, t}\right)\right]=0$ for $s=1 ; t=3, \ldots, T$

Moment conditions for endogenous, predetermined, and exogenous variables in the level equations are omitted here to save space. Corresponding to each period, instruments for the system develops into a complete matrix and system GMM estimators are derived from the system. ${ }^{17}$

A step further from the standard application GMM system estimators is that two techniques developed by Roodman (2006) are adopted to overcome specific data problems of this study. First, there are significant gaps in the data-set. First-difference transformations (equation 5) magnify these data gaps, so orthogonal deviations recommended by Roodmand (2006) are employed to minimise data loss. ${ }^{18}$ Furthermore, as the number of the cross-section $(\mathrm{N})$ is small in this analysis, instruments easily outnumber $\mathrm{N}$, which is a signal of the problem of 'too many instruments'. The implications are that the instruments may have 'overfit endogenous variables' and weaken the specification tests. A possible way to control this is to 'collapse' the instruments to reduce the number of instruments without losing much information from the data (Roodman 2006 and 2008).

Consistency of the estimators relies on validity of the instruments, which are linked to the above-mentioned conditions. To verify instrument validity, two specification tests in the computer packages are used. First, the M2 test tests second-order correlation of the error term. Second, the Sargan test examines for over-identifying restrictions or, in other words, the validity of the instruments.

\section{Data}

A cross-province panel data-set is employed in this study. This consists of annual data of 
all 31 provinces in China including four provincial level municipalities (currently Beijing, Shanghai, Tianjin, and Chongqing). Data are collected for the period 1999-2006. It is a balanced panel yet it contains gaps especially in the data series of private credits. As shown in the summary statistics (Table 2), the shortest series of credits to foreign enterprises reduces the total number of observations by more than one third.

Nevertheless, this study makes the best use of the latest data available across provinces. More importantly, it is the first study of the credit situation among sub-groups of private enterprises to examine their individual relationship with FDI benefits. Several ownership types exist in China under the cap of private enterprises, including individual and private enterprises (PRVs), township and village enterprises (TVEs), and enterprises with foreign capital (FORs). Compared to state-owned enterprises, the three types all deliver higher returns to investment and achieve higher productivity, which is solid evidence of their non-state ownership superiority (MGI 2006). However, in terms of their financing situations, they show significant heterogeneity. Despite the lending bias against non-state firms, Huang (2003) reveals that within the non-state category TVEs are substantially favoured over PRVs by Chinese banks. This may be partly due to the fact that many TVEs are effectively controlled by local governments that have strong influence over lending decisions of local bank branches (MGI 2006). At the same time, the financial situation of foreign firms (FORs) is different from others because they have direct and easier access to foreign capital from overseas. But like TVEs, they are also in a better position than private individual firms whose financing options are extremely constrained, sometimes to the only option of costly informal financing for survival (IFC 2000). ${ }^{19}$ Overall, divergences among credit lines and credit accessibility for each sub-group are large and significant. Hence, it is essential to distinguish them from each other for any useful policy implications to be gained.

The main data source for the sub-groups of private credits is individual provincial statistical yearbooks. All three sub-group data series are under the short-term loan category of all financial institutions operating in each province. ${ }^{20}$ As stock markets are not well developed in China, firms rely on debt, especially short-term debt, for financing investment. Short-term loan portfolios of financial institutions thus reveal how financial resources are allocated and how firms of different ownership are financed. FDI inflows are measured by 'actually utilised amount of direct foreign investment', in contrast to the contract amount. Until 2003, data of the former were available in the China Statistical Yearbook (CSY). Since 2004, CSY only reports the contract amount. As a result, post-2003 FDI data are sourced in publications of the Ministry of Commerce to keep data consistency. Aggregate financial data are mainly from the Almanac of China's Finance and Banking and other data for variables of the growth equation are mainly from CSY. A detailed description of 
Asia Pacific Economic Papers

data definitions and sources is included in Table 1.

\section{Results}

Within-group, Difference GMM, and System GMM estimators are reported for comparison with the final results using System GMM - Roodman extension estimators (Table 4). For system GMM estimators and Roodman extension estimators, one-step estimators are reported in association with different financial indicators respectively. ${ }^{20}$ Table 4 records results related to total credits. Table 5 and Table 6 reports results associated with subgroups of private credits in comparison with total credits and non-private credits. For all groups, the baseline models are first tested to see the individual correlation of FDI and financial market development with growth. Then the expanded models or test models with the interaction terms are examined to reveal how local financial intermediation may affect FDI benefits in China.

Within-group estimators and Different GMM estimators in Table 4 show results of similar pattern, in terms of coefficient signs and significance levels. As discussed in Section 4 , the within-groups estimation provides biased estimator of initial level of income (l.y) (Models 1 and 2), whereas Difference GMM estimators are biased downward as a result of a small sample (Models 3 and 4). System GMM estimators overcome the small sample bias associated with difference GMM estimators. However, System GMM estimators create a new problem - 'too many instruments' that could 'overfit endogenous variables'. Instruments increase from 134 to 176 for the baseline models (Models 3 and 5) and from 141 to 189 for the test models (Models 4 and 6). Roodman's techniques help to significantly reduce the number of instruments by two thirds (Models 7 and 8). As a result, the significance level of endogenous variables such as education and population all drop considerably. Nevertheless, the Roodman extension of System GMM provides the most consistent and unbiased estimators among the available estimation methods.

The first observation from the results is that the augmented Solow-growth model is appropriate for describing provincial growth pattern in China. Initial income has strong explanatory power for economic growth in all equations. However, a positive coefficient shows a picture of growth divergence (Models 7 and 8), instead of convergence that is observed in cross-country studies. The past decade has seen income inequalities rising rapidly across regions in China. Many recent studies confirm that economic reforms have widened the income gap between different provinces at least in the short term (Luo and Zhu 2008). In addition to initial income, education also display positive and highly significant coefficient, highlighting the important factors contributing to local growth in China. Nevertheless, due to data limitations, this is a short-term trend observed from the 
period 1999-2006.

FDI and financial indicators are key variables in this study. FDI per se has no statistically significant effects on growth and in the baseline model (Model 7 in Table 4) its coefficients even show puzzling negative signs. Other studies have reported similar insignificant results (Luo 2007), which are in contrast to what the traditional FDI growth theory would predict - a strong positive correlation between FDI and economic growth (King and Levine 1993). However, in our study this result is not surprising as poor growth response to FDI is one of the reasons that have motivated this study to reveal the mechanism of FDI benefits working in China.

Another motivation comes from evidence of perverse local financial market development, so it is not surprising to see that total credits enter the equation statistically significantly, with negative signs (Model 7 in Table 4). The results indicate that a larger financial sector is often associated with less growth cross Chinese provinces. In other words, financial resources fail in helping the local economy to grow as in many other places (Levine et al. 2000). Worse, loans tend to restrain growth in China. This empirical evidence resembles the results of other studies including that of Guariglia and Poncet (2007). As explained in those studies, financial institutions in China misallocate financial resources. They channel the disproportionately large amount of credit to support unproductive segments of the economy, leaving the most dynamic part of the economy in credit constraint. As a result, the more credits are expanded, the more they are used to support ailing SOEs resulting in further economic loss and overcapacity. ${ }^{21}$ The notorious feature of credit misallocation prevalent in Chinese financial institutions explains the negative finance-growth nexus in China. Total deposits show a similar pattern because savings are used to finance loans to unproductive SOEs. These entail similar harmful impacts on growth as loans do.

The main task of this study is to examine how financial sector development influences the effects of FDI on growth and this is examined by means of interaction terms. First, as shown in regression (Model 8 in Table 4), the interaction term of FDI with total credits enters in the regression highly significantly, at the one per cent level, and its coefficient shows a negative sign, which suggests the significant influence of financial markets on FDI's effects on growth and the influence is detrimental. Perhaps more importantly, the coefficient associated with FDI changes significantly positive at a 10 per cent level, after the interaction term is added. The results reveal the counterfactual scenario that once the negative impact of financial markets on FDI-growth linkage is separated out, the original FDI-growth relationship is positive.

To interpret this in a different way, the result (Model 8 in Table 4) helps to explain why the coefficients of FDI in the baseline models (Model 7 in Table 4) are negative. It is because financial market conditions overthrow FDI's otherwise positive effects. The 
correlation between FDI and growth is 0.0177 (Model 8 in Table 4), and the correlation between the FDI-loan interaction term and growth is -0.0207 . Thus, including the negative effects of loans on FDI growth correlation, the observed FDI effects on growth in total is -0.0030 .

The next question is whether all credits have the same harmful effects on the FDI- growth relationship as total credits reveals. Data on credits to SOEs are non-existing on the provincial level, so are the data on private credits. To distinguish possibly different effects associated with different type of borrowers, sub-groups of private credits are included in regressions (Table 5 and Table 6). However, the data sets are small by size and further limited by data gaps, so each sub-group of private credits is examined separately because each has a different sample due to data availability. Also, due to the different samples and data availability, disaggregation of total credits into non-private credits and private credits reduces the size of the whole sample significantly, by two third, and therefore limits the power of estimation.

Non-private credits are derived from total credits minus the sum of all sub-groups of private credits. Comparing the results in Table 5 suggests that non-private credit negatively influence growth whereas credits to private and individual enterprises $(\mathrm{CP})$ positively contribute growth, as expected. However, the regressions fail to capture other significant relationships mainly due to the small sample size.

An alternative method to overcome the small size problem is to use total credits to proxy SOE credits for comparison. ${ }^{22}$ Based on the national aggregate data that loans to SOEs dominate loan portfolios of financial institutions and loans, total credits are assumed to capture the pattern of credits to SOEs in each province. One drawback as a consequence is the concern of multicollinearity between total credits and private credits since the former contains the latter. Nevertheless, values of private credits are extremely small compared to those of total credits (Table 2), so multicollinearity is expected to be not a serious issue.

An important result from this set of regressions is that private credits show different effects among sub-groups (Table 6). First, the variable of credits to private and individual enterprises $(\mathrm{CP})$, also characterised as small private enterprises, displays a significantly positive coefficient at the five per cent level (Model 12 in Table 6). The result confirms the productiveness of small private enterprises, suggesting more credits to this group would promote growth. More importantly, CP's interaction with FDI is significant and positive at a high significance level. That is to say, the combined effects of FDI and credits to small private enterprises on growth are positive. There could be two interpretations for this result: one being the marginal product of CP increases with more FDI; and the other being the marginal product of FDI increases with more credits to these enterprises. The first interpretation suggests that small private enterprises learn and benefit from FDI presence 
so that they produce more return on loans. The second interpretation is that the marginal product of FDI increases as a result of more local business supported by the credit line absorbing the FDI benefits. So FDI generates more output through its positive spill-overs to lift the output of local businesses. The two interpretations are essentially one, reflecting the complementary nature of FDI and productive local enterprises in their relationship with output growth.

The second group of private credits examined is credits to township and village enterprises (CT). CT per se has a significant and positive effect on growth (Model 13 in Table 6). Like credits to small private enterprises, marginal products of credits to township and villages are positive. It is a productive force of growth. However, the interaction term with FDI in the regression has lost explanatory power. In other words, the mutually reinforcing mechanism with FDI observed in small private enterprises seems not to be working for township and village enterprises. This may be due to their implicitly close relationship with the government. For a further comparison, the third category of domestic credits to foreign-funded enterprises has neither significant impact on growth directly nor any effects through interaction with foreign capital (Model 14 in Table 6).

Total credits are included in all regressions associated with private credits to proxy SOE credits. They have negative coefficients in all regressions and the coefficients are significant. Provided that credits to SOEs constitute the major part of total credits and credits to private enterprises are either insignificantly positive or insignificant, the significant and negative coefficients associated with total credits indicate the strong counter-growth effects of SOE credits. Moreover, the coefficients of this interaction with FDI are negative and highly significant, indicating that SOE credits have a detrimental effect on FDI benefits as well. As shown in the interpretation of CP's interaction, the mechanism also works from both sides, though in an opposite way. Marginal products of SOE credits decline with more FDI coming because most SOEs are unproductive in China. They are historically protected by the state and therefore least motivated to learn from FDI. With greater FDI flows increasing competitive pressure in the country, SOEs often fail in the competition with foreign firms and produce less and less output. As a consequence, SOEs unproductiveness offsets the marginal product of FDI or the FDI benefits.

In sum, the results support the Alfaro et al. model on the role of local financial development in FDI benefits. But to best explain the complexity of the situation in China, a distinction between good and bad financial intermediation is needed. Credits to small private enterprises are a measure of good financial intermediation in China. Expanded credits to this group indicate a more efficient financial system because the system intermediates financial resources to the most productive section of the economy, which also has the most capacity to absorb FDI benefits. So such a system magnifies FDI benefits. By contrast, 
credits to SOEs provide an indicator of poor financial intermediation in China because they allow resources to be channeled to the most unproductive part of the economy, which has the least capability as well as the least incentive to learn from FDI. Hence FDI benefits are severely diminished. Hence, the China case provides support to the model in both ways. Good financial intermediation strengthens the FDI-growth linkage, while poor financial intermediation offsets the FDI-growth benefits.

The specification tests include M2 tests (the second order auto-correlation test) and Hansen tests. Their results are reported for each regression in the result table. The M2 test fails to reject the absence of second-order serial correlations in all regressions. The Hansen test also fails to reject the null hypothesis of the validity of over-identifying restrictions. Both test results suggest that the instruments used are valid. In addition, though the test results are not included in the table, all the regressions pass a set of Difference-in-Hansen tests for testing the exogeneity of instrument subsets. As a whole, use of the system GMM is justified.

Finally, two strategies are adopted to test the robustness and sensitivity of the results. First, in an attempt to smooth over short-term business cycle turbulence, two-year averages are used to approximate steady-state values. This is only applicable for regressions involving total credits and total deposits, not for sub-groups of private credits as the averaging reduces samples to unusable. However, for applicable cases, similar results are obtained to those from the annual data. The second strategy is to test a sub-sample of data, excluding three municipality outliers (Beijing, Tianjin, and Shanghai). Again, the main results still hold.

\section{Conclusion}

The study explores the reason why FDI appears to have had limited impact on economic growth in China. It applies the Alfaro et al. model to investigate whether financial sector development plays a role in this weak FDI-growth linkage. A dynamic panel data model is estimated by Blundell-Bond system GMM estimators over a cross-province data-set for the period 1999-2006. The key result from the study is that financial development indeed plays a role in FDI-growth linkage in China. Poor financial intermediation substantially offsets FDI's potential benefits on local economic growth. This explains why a large amount of FDI inflows has not been accompanied by strong positive growth effects in China as found in many other countries.

Two policy implications can be drawn from the empirical findings. First, the direct policy implication is that to ensure positive benefits from FDI in China, domestic financial reforms are crucial. This is an important perspective for making FDI policies. In addi- 
tion to fiscal and financial incentives to attract more FDI in the early years of economic reform, the capacity building literature has recently offered many suggestions on how to effectively utilise FDI, such as improving technical training, building linkages between local and foreign firms, and increasing labor mobility (Fan and Hu 2007; Ran et al. 2007). On top of capacity building programs, this study highlights a stronger role for local financial development in realising FDI benefits in China, because the financial system is basic and fundamental for a dynamic private sector to exist, grow, and then be able to learn from FDI.

The results also reveal some key priorities of financial reforms. More credits to small private enterprises are an indication of good financial intermediation, while more loans extended to unproductive SOEs signal poor financial intermediation. The priority of reform comes down to tackling the difficult problem of credit misallocation. Loan distribution in China is not commercially based and far from efficient. It calls for fundamental changes in financial institutions' lending behaviour, which is a multi-dimensional complicated policy challenge. The study is not designed to shed light on this issue, but a review of the financial system in China suggests that state intervention/protection still exists in most Chinese banks as well as in state enterprises. This prevents banks from making commercially viable decisions and delays the fundamental reforms in SOEs. Maybe the challenge remains to liberalise the economy and remove state intervention from micromanagement.

Finally, the study is constrained by data availability especially for private credit data across provinces. Also, there is a lack of advanced econometric technology to totally overcome the 'too many instruments' problem associated with the data, though some techniques have been employed to address the issue. Both problems are expected to be solved in future research. Moreover, from the theoretical point of view, future efforts could be directed to incorporating the SOE sector in the Alfaro et al. model. 


\section{Appendix}

This appendix reviews the Alfaro et al. (2003) model. It demonstrates how the financial system influences the number of local entrepreneurs that can absorb FDI spill-overs, which decides the actual FDI benefits to be materialised locally. The model assumes a small, open economy consisting of two sectors: the foreign production sector and the domestic production sector.

\section{Foreign production sector}

The foreign production sector follows a standard constant-returns-to-scale Cobb-Douglas production function. It uses domestically supplied labour and foreign capital, $Y_{t}^{F D I}=A L_{t}^{\beta}\left(K_{t}^{F D I}\right)^{1-\beta}$

from which the international rate of interest, and the wage rate, in the foreign sector can be derived,

$$
\begin{aligned}
& r=(1-\beta) A L_{t}^{\beta}\left(K_{t}^{F D I}\right)^{-\beta} \\
& \left.w=\beta A^{\frac{1}{\beta}}\left(\frac{(1-\beta)}{r}\right)\right)^{\frac{1-\beta}{\beta}}
\end{aligned}
$$

The stock of foreign capital is also obtained,

$$
K_{t}^{F D I}=\left(\frac{(1-\beta) A}{r}\right)^{\frac{1}{\beta}} L_{t}
$$

\section{Domestic production sector}

The domestic product is modeled as a sum of individual domestic entrepreneurs' output. First, the economy is assumed to be populated by a continuum of agents of total mass 1 , indexed by their level of ability $\varepsilon_{t}^{i}$, following a standard uniform distribution, $\varepsilon_{t}^{i} \in(0,1)$ (Figure 1). Then, there exists a threshold level of ability $\varepsilon_{t}^{*}$, above which agents become entrepreneurs and undertake entrepreneurial activities in the domestic production sector. Subject to a fixed investment $S$, each entrepreneur produces output $Y_{t}^{i}$ benefiting from the presence of FDI $K_{t}^{F D I}$.

$Y_{t}^{i}=\varepsilon_{t}^{i} B\left(K_{t}^{F D I}\right)^{\theta} S^{\gamma},(0<\theta<1 ; 0<\gamma<1)$

So the domestic output is the sum of the outputs produced by all these entrepreneurs, 


$$
Y_{t}^{D O M}=\int_{\varepsilon_{t}^{*}}^{1} Y_{t}^{i} d \varepsilon
$$

The threshold level of ability divides agents into two groups. The first group consists of agents having above-threshold ability and subsequently become entrepreneurs working in the domestic production sector with a total amount equal to $\varepsilon_{t}^{*}$. The second group has agents of below-threshold ability. They then join the labour force of the foreign sector equal $\left(1-\varepsilon_{t}^{*}\right)$.

Figure 1 The cumulative distribution function (CDF) of the standard uniform distribution of the ability level $\varepsilon_{t}^{i}$

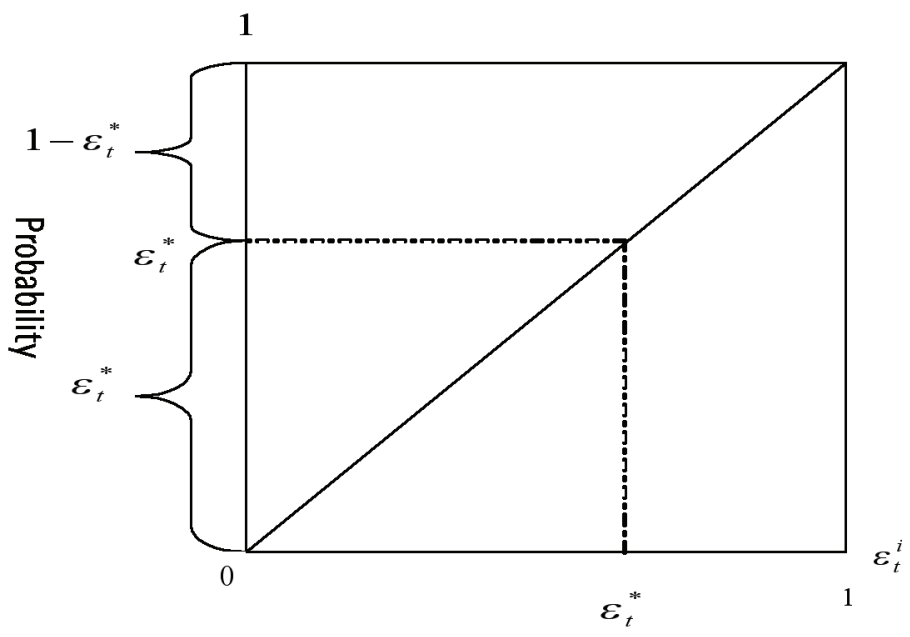

The assumption of agents' ability level following a standard uniform distribution simplifies the algebra without loosing generality of the model. As shown in Figure 1, the probability for an agent to take on an ability level equal or below the threshold level ability is $\varepsilon_{t}^{*}$, so the percentage of the agents who work in the foreign sector is $\varepsilon_{t}^{*}$, which is also the total amount of labor employed in the foreign production sector since the total population of agents is normalised to 1 . Likewise, the probability for an agent to have an above- threshold level of ability is $\left(1-\varepsilon_{t}^{*}\right)$, so the amount of agents who become entrepreneurs and engage domestic production is $\left(1-\varepsilon_{t}^{*}\right)$.

\section{Housebold and occupational choice}

The threshold level of ability is decided by the agents' occupational choice based on the 
income streams associated with each choice. Agents who choose to work for a foreign company earn an income stream equal to their wages $w$ plus the return on their level of assets $b_{t-1}$ at the beginning of the period, $w+(1+r) b_{t-1}$. Those who choose to produce in the domestic sector must pay off their loans at the end of the period and therefore earn a net income of $Y_{t}^{i}-(1+i)\left(s-b_{t-1}\right)$. An agent is indifferent between working for the foreign firm and starting its own business if the incomes earned are the same,

$$
w+(1+r) b_{t-1}=Y_{t}^{i}-(1+i)\left(s-b_{t-1}\right)
$$

Substitute for $Y_{t}^{i}$ and $w$ in equation (2), the break-even level ability is the threshold level of ability,

$$
\varepsilon_{t}^{*}=\left[\frac{(1+r+\delta)\left(S-b_{t-1}\right)+\beta A^{\frac{1}{\beta}}\left(\frac{1-\beta}{r}\right)^{\frac{1-\beta}{\beta}}+(1+r) b_{t-1}}{B\left(\frac{A(1-\beta)}{r}\right)^{\frac{\theta}{\beta}} S^{\gamma}}\right]^{\frac{1}{1+\theta}}
$$

The role of the financial market efficiency appears in the model due to its role in determining the threshold ability level and therefore the number of entrepreneurs that can benefit from FDI spillovers. Financial inefficiency is measured as $\delta$, the difference between the lending rate $r$ and the borrowing rate $i$. A bigger $\delta$ indicates higher financial costs which characterizes an inefficient financial system. From this equation, $\partial \varepsilon_{t}^{*} / \partial \delta>0$, which suggests a higher level of financial efficiency increases the number of entrepreneurs.

Comparative statistics

Comparative statistics reveal how FDI's output effects hinge on local financial market conditions. First, the total output of the economy is:

$Y_{t}=Y_{t}^{F D I}+\left(1-\varepsilon_{t}^{*}\right) B\left(K_{t}^{F D I}\right)^{\theta} S^{\gamma}$

So the total effect of FDI on output is:

$$
\frac{\partial Y_{t}}{\partial K_{t}^{F D I}}=r+\left(1-\varepsilon_{t}^{*}\right) B \theta\left(K_{t}^{F D I}\right)^{\theta-1} S^{\gamma}>0(\mathrm{~A}-7)
$$

However, FDI effects depend on local financial intermediation because:

$$
\frac{\partial^{2} Y_{t}}{\partial K_{t}^{F D I} \partial \delta}<0
$$

An improvement in the financial sector increases the number of domestic entrepreneurs and therefore increases the marginal product of FDI. In other words, an efficient financial system enhances FDI's output effects whereas an incompetent financial system diminishes 
FDI effects.

\section{References}

ACFB 2003. Almanac of China's Finance and Banking 2003, Beijing: China's Financial Publication House.

Alfaro, L., Chanda, A., Kalemli-Ozcan, S. and Sayek, S., 2003. 'FDI Spillovers, Financial Markets, and Economic Development'. IMF Working Paper, WP/03/186.

Alfaro, L., Chanda, A., Kalemli-Ozcan, S. and Selin, S., 2004. 'FDI and economic growth: the role of local financial markets'. Journal of International Economics, 64:89-112.

Arellano, M. and Bond, S., 1991. 'Some Tests of Specification for Panel Data: Monte Carlo Evidence and an Application to Employment Equations'. Review of Economic Studies, 58: 277-297.

Bayoumi, T. and Lipworth, G., 1998. 'Japanese foreign direct investment and regional trade'. Journal of Asian Economics, 9: 581-607.

Benhabib, J. and Spiegel, M. M., 2000. 'The Role of Financial Development in Growth and Investment'. Journal of Economic Growth, 5.

Blomstrom, M. and Kokko, A., 1998. 'Multinational Corporations and Spillovers'. Journal of Economic Surveys, 12:247-277.

Blundell, R. and Bond, S., 1998. 'Initial conditions and moment restrictions in dynamic panel data models'. Journal of Econometrics, 87:115-143.

Bond, S., Hoeffler, A. and Temple, J., 2001. 'GMM Estimation of Empirical Growth Models'. University of Oxford Economics Papers, 2001-W21.

Boyreau-Debray, G., 2003. 'Financial Intermediation and Growth: Chinese Style'. Policy Research Working Paper 3027.

Caselli, F., Esquivel, G. and Lefort, F., 1996. 'Reopening the Convergence Debate: A New Look at Cross-Country Growth Empirics'. Journal of Economic Growth, 1.

Cheng, X. and Degryse, H., 2006. 'The Impact of Bank and Non-Bank Financial Institutions on Local Economic Growth in China'. Discussion Paper, Tilburg University.

China Enterprise Director's Association, 2007. A Report on the Development of China's Enterprises 2007, Enterprise Management Publishing House, Beijing.

China Ministry of Commerce, 2003-2006. Report on Foreign Direct Investment in China, http:// www.fdi.gov.cn/pub/FDI/wzyj/yjbg/default.jsp (11/12/2009)

China Statistical Yearbook (CSY), 1999-2003. China Statistical Yearbook 1999-2003, Beijing, China Statistics Press.

Fan, C. S. and Hu, Y., 2007. 'Foreign direct investment and indigenous technological efforts: evidence from China'. Economics Letters, 96:253-258.

Firebaugh, G. and Gibbs, J. P., 1985. 'User's Guide to Ratio Variables'. American Sociological Review, 50:713-722.

Garnaut, R., Song, L., Yang, Y. and Wang, X., 2001. Private Enterprises in China, Canberra, Asia Pacific Press.

Guariglia, A. and Poncet, S., 2007. 'Could financial distortions be no impediment to economic growth after all? Evidence from China'. Journal of Comparative Economics, 36:633-657.

Guillaumont Jeanneney, S., Hua, P. and Liang, Z., 2005. 'Financial Development, Economic Efficiency, and Productivity Growth: Evidence from China'. The Developing Economies, XLIV-1:27-52.

Hale, G. and Long, C., 2007. 'Are there Productivity Spillovers from Foreign Direct Investment in China?' Federal Reserve Bank of San Francisco Working Paper 2006-13. 
Hao, C., 2006. 'Development of financial intermediation and economic growth: The Chinese experience'. 2006, 17:347-362.

Hsiao, C.,1986. Analysis of Panel Data, Cambridge, Cambridge University Press.

Huang, Y., 2003. Selling China, Cambridge, Cambridge University Press.

International Finance Corporation, 2000. China's Emerging Private Enterprises: Prospects for the New Century, International Finance Corporation.

International Monetary Fund, 2000. 'Transition Economies: An IMF Perspective on Progress and Prospects'. IMF Issues Briefs.

King, R. G. and Levine, R., 1993. 'Finance and growth: Schumpeter might be right'. Quarterly Journal of Economics, 108:120-143.

Laurenceson, J. and Tang, K. K., 2007. 'The FDI- income growth nexus: a review of the Chinese experience'. EAERG Discussion Paper Series, University of Queensland, School of Economics.

Levine, R., Loayza, N. V. and Beck, T., 2000. 'Financial intermediation and growth: causality and causes'. Journal of Monetary Economics, 46:31-77.

Li, J., 2008. 'China's financial market fragmentation', 1978-2004. Munich Personal RePec Archive, 8176.

Lu, D., Thangavelu, S. M. and Hu, Q., 2005. 'Biased Lending and Non-performing Loans in China's Banking Sector'. The Journal of Development Studies, 41:1071-1091.

Luo, C., 2007. 'FDI, domestic capital and economic growth: evidence from panel data at China's province level'. Frontiers of Economics in China, 2:92-113.

Luo, X. and Zhu, N., 2008. 'Rising Income Inequality in China: A Race to the Top'. World Bank Policy Research Working Paper, 4700.

Mankiw, N. G., Romer, D. and Weil, D. N., 1992. 'A Contribution to the Empirics of Economic Growth'. The Quarterly Journal of Economics, 107:407-437.

McKinsey Global Institute, 2006. Putting China's Capital to Work: The Value of Financial System Reform, McKinsey Global Institute.

Nickell, S., 1981. 'Biases in Dynamic Models with Fixed Effects'. Econometrica, 49: 1417-1426.

Park, A. and Sehrt, K., 2001. 'Tests of Financial Intermediation and Banking Reform in China'. Journal of Comparative Economics, 29:608-644.

Podpiera, R., 2006. 'Progress in China's Banking Sector Reform: Has Bank Behaviour Changed?' IMF Working Paper, WP/06/71.

Ran, Jimmy and Voon, Jan P. and Li, Guangzhong, 2007. 'How does FDI affect China? Evidence from industries and provinces', Journal of Comparative Economics, 35(4): 774-799.

Roodman, D., 2006. 'How to Do xtabond2: An Introduction to "Difference" and "System" GMM in Stata'. Centre for Global Development Working Paper, 103.

Roodman, D., 2008. 'A Note on the Theme of Too Many Instruments'. Centre for Global Development Working Paper, 125.

Wong, R. and Wong, S., 2001. 'Competition in China's Domestic Banking Industry'. Cato Journal, 21:19-41.

Yu, Y.D. 2009. 'China's Policy Response to the Global Financial Crisis', presented in ANU College of Asia and the Pacific seminar series, 27 November 2009, Canberra. 
No. 383, 2009

\section{Statistical tables}

Table 2 Variable definitions and sources

\begin{tabular}{|c|c|c|}
\hline Variables & Description & Source \\
\hline $\begin{array}{l}\text { Dependent Variable } \\
\text { GDP per capita }(y)\end{array}$ & $\begin{array}{l}\text { Real GDP ( } 1999 \text { constant price) / } \\
\text { working age population }\end{array}$ & $\begin{array}{l}\text { China Statistical Yearbook } \\
\text { (CSY), various years }\end{array}$ \\
\hline \multicolumn{3}{|l|}{$\begin{array}{l}\text { Explanatory Variables } \\
\text { 1. FDI Variables }\end{array}$} \\
\hline FDI per capita $(f d i)$ & $\begin{array}{l}\text { *Real FDI inflows ('actually used } \\
\text { amount of direct foreign investment') } \\
\text { / working age population }\end{array}$ & $\begin{array}{l}\text { CSY (1999-2003); The } \\
\text { Ministry of Commerce, } \\
\text { PRC (2004-2006) }\end{array}$ \\
\hline \multicolumn{3}{|l|}{ 2. Financial Indicators } \\
\hline $\begin{array}{l}\text { Total loans per capita } \\
(\text { loan })\end{array}$ & $\begin{array}{l}\text { Real total loans / working age } \\
\text { population }\end{array}$ & $\begin{array}{l}\text { Almanac of China's } \\
\text { Finance and Banking } \\
(\text { ACFB }) \text {, various years }\end{array}$ \\
\hline $\begin{array}{l}\text { Total deposits per } \\
\text { capita }(\text { depo })\end{array}$ & $\begin{array}{l}\text { Real total deposits / working age } \\
\text { population }\end{array}$ & $\mathrm{ACFB}$, various years \\
\hline $\begin{array}{l}\text { Township credits per } \\
\text { capita }(c t)\end{array}$ & $\begin{array}{l}\text { Real credits to the township } \\
\text { enterprises / working age } \\
\text { population }\end{array}$ & $\begin{array}{l}\text { Statistical yearbook of } \\
\text { individual provinces, } \\
\text { various years }\end{array}$ \\
\hline $\begin{array}{l}\text { Private credit per } \\
\text { capita }(c p)\end{array}$ & $\begin{array}{l}\text { Real credits to the private and } \\
\text { individual enterprises / working age } \\
\text { population }\end{array}$ & $\begin{array}{l}\text { Statistical yearbook of } \\
\text { individual provinces, } \\
\text { various years }\end{array}$ \\
\hline $\begin{array}{l}\text { Foreign credits per } \\
\text { capita }(c f)\end{array}$ & $\begin{array}{l}\text { Real credits to foreign enterprises / } \\
\text { working age population }\end{array}$ & $\begin{array}{l}\text { Statistical yearbook of } \\
\text { individual provinces, } \\
\text { various years }\end{array}$ \\
\hline \multicolumn{3}{|c|}{ 3. Growth Determinants } \\
\hline $\begin{array}{l}\text { Investment GDP ratio } \\
(\text { inv })\end{array}$ & $\begin{array}{l}\text { Ratio of investment in fixed assets } \\
\text { to nominal GDP }\end{array}$ & CSY, various years \\
\hline Human capital $(e d u)$ & $\begin{array}{l}\text { Ratio of population with educational } \\
\text { attainment of college and any higher } \\
\text { level in the total population age } \geq 6\end{array}$ & $\begin{array}{l}\text { China Population } \\
\text { Statistics Yearbook } \\
\text { (CPSY) and CSY, } \\
\text { various years }\end{array}$ \\
\hline $\begin{array}{l}\text { Population growth } \\
(p \circ p)\end{array}$ & $\begin{array}{l}\text { Growth rate of working age } \\
\text { population }\end{array}$ & CSY, various years \\
\hline $\begin{array}{l}\text { Government exp. } \\
\text { GDP ratio (gov) }\end{array}$ & $\begin{array}{l}\text { Ratio of government expenditure to } \\
\text { nominal GDP }\end{array}$ & CSY, various years \\
\hline $\begin{array}{l}\text { Trade volume per } \\
\text { capita (trade) }\end{array}$ & $\begin{array}{l}\text { Real value of exports and imports / } \\
\text { working age population }\end{array}$ & CSY, various years \\
\hline
\end{tabular}

*: all the nominal terms are transformed into real terms using GDP deflators. 
Asia Pacific Economic Papers

Table 3 Summary statistics

\begin{tabular}{lccccc}
\hline Variable & Obs. & Mean & Std. Dev. & Min & Max \\
\hline GDP per capita & 248 & 2.368878 & 1.813497 & 0.461488 & 11.849220 \\
& & & & & \\
Inv./GDP & 248 & 0.420191 & 0.114749 & 0.241852 & 0.794273 \\
Labour growth & 248 & 1.015750 & 0.026392 & 0.953728 & 1.269022 \\
Edu. & 248 & 0.056833 & 0.042562 & 0.000900 & 0.293600 \\
Gov./GDP & 248 & 0.166440 & 0.110811 & 0.046791 & 0.827598 \\
SOE & 248 & 0.466765 & 0.142286 & 0.155600 & 0.958900 \\
Trade per capita & 248 & 1.356358 & 2.923473 & 0.022900 & 20.732300 \\
& & & & & \\
FDI per capita & 248 & 0.073058 & 0.120426 & 0.000000 & 0.628700 \\
& & & & & \\
Loan per capita & 248 & 2.802550 & 3.180300 & 0.512620 & 18.253200 \\
TVE credits per capita & 177 & 0.101137 & 0.143750 & 0.000021 & 0.703850 \\
PRV credits per capita & 168 & 0.025116 & 0.036316 & 0.001274 & 0.252479 \\
FOR credits per capita & 163 & 0.049691 & 0.100387 & 0.000072 & 0.691445 \\
\hline
\end{tabular}




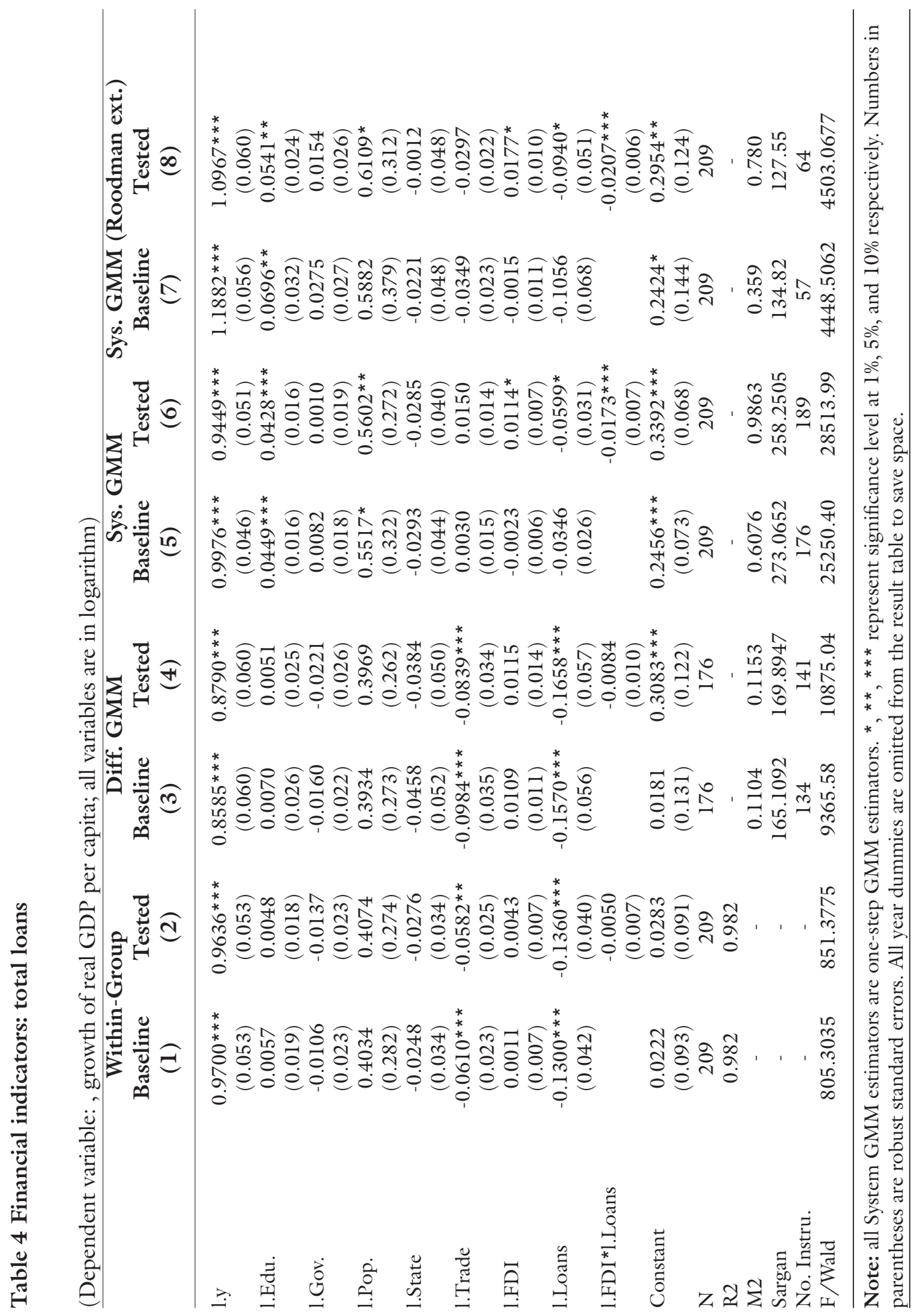


Asia Pacific Economic Papers

Table 5 Financial indicators: credits to private and individual enterprises (cp), to township and village enterprises (ct), and to foreign funded enterprises (cf)

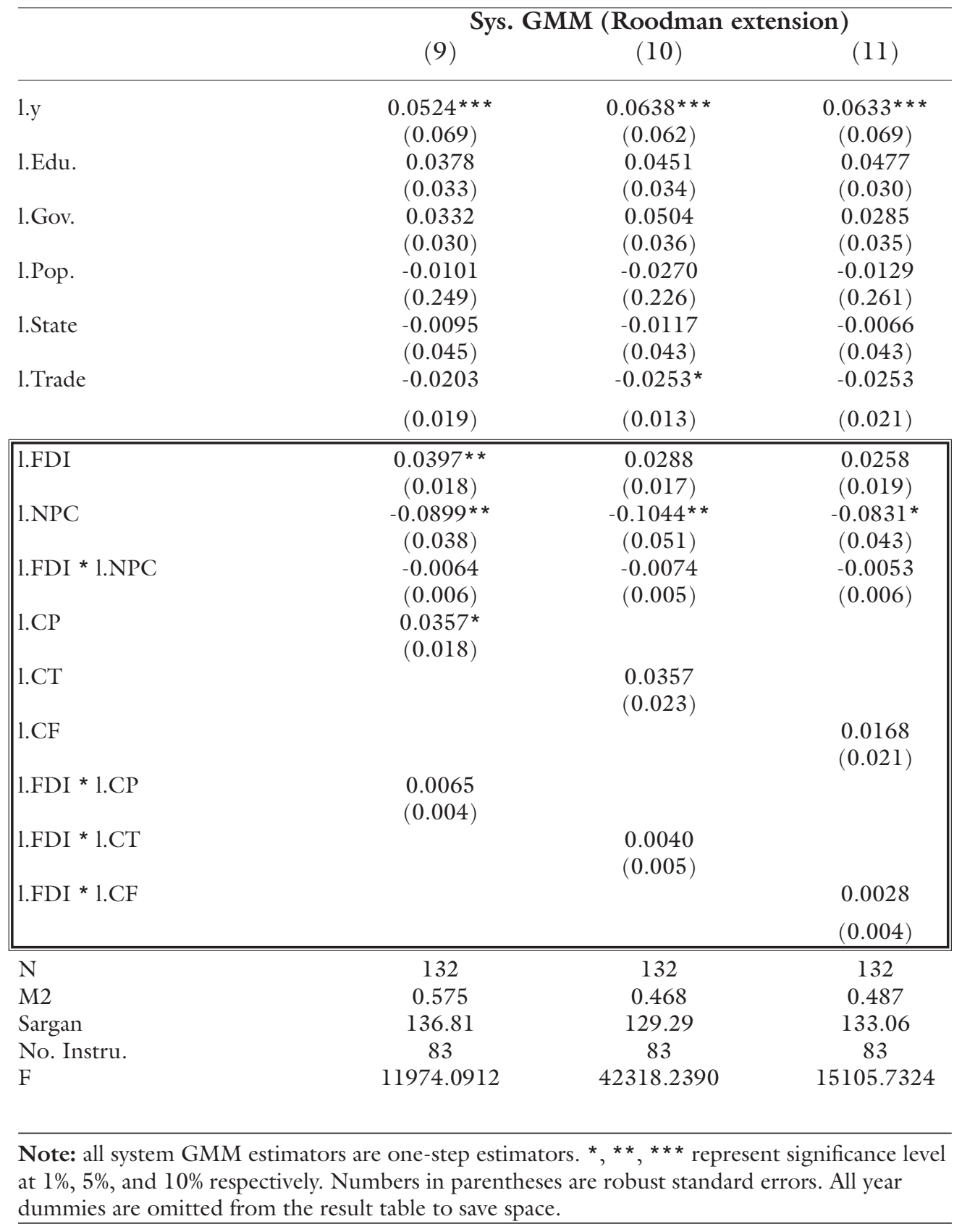


Table 6 Financial indicators: credits to private and individual enterprises (cp), to township and village enterprises (ct), and to foreign funded enterprises (cf)

(Dependent variable: $y_{i, t}-y_{i, t-1}$, growth of real GDP per capita)

\begin{tabular}{|c|c|c|c|}
\hline & \multicolumn{3}{|c|}{ Sys. GMM (Roodman extension) } \\
\hline & $(12)$ & $(13)$ & (14) \\
\hline 1.y & $\begin{array}{c}0.0041 \text { ** * } \\
(0.075)\end{array}$ & $\begin{array}{c}0.0348 * * * \\
(0.060)\end{array}$ & $\begin{array}{c}0.0122 * * * \\
(0.082)\end{array}$ \\
\hline 1.Edu. & $\begin{array}{l}0.0343 \\
(0.030)\end{array}$ & $\begin{array}{c}0.0769 * * * \\
(0.029)\end{array}$ & $\begin{array}{c}0.0593 \\
(0.037)\end{array}$ \\
\hline 1.Gov. & $\begin{array}{l}0.0071 \\
(0.023)\end{array}$ & $\begin{array}{l}0.0206 \\
(0.023)\end{array}$ & $\begin{array}{c}0.0030 \\
(0.029)\end{array}$ \\
\hline 1.Pop. & $\begin{array}{c}0.0173 \\
(0.273)\end{array}$ & $\begin{array}{c}0.0671 \\
(0.240)\end{array}$ & $\begin{array}{r}-0.0304 \\
(0.270)\end{array}$ \\
\hline 1.State & $\begin{array}{r}-0.0172 \\
(0.044)\end{array}$ & $\begin{array}{c}-0.0524 \\
(0.049)\end{array}$ & $\begin{array}{r}-0.0405 \\
(0.051)\end{array}$ \\
\hline 1.Trade & $\begin{array}{r}-0.0288 \\
(0.021)\end{array}$ & $\begin{array}{c}-0.0449 \text { ** } \\
(0.022)\end{array}$ & $\begin{array}{r}-0.0288 \\
(0.028)\end{array}$ \\
\hline 1.FDI & $\begin{array}{c}0.0466^{* *} \\
(0.019)\end{array}$ & $\begin{array}{c}0.0387^{* * *} \\
(0.013)\end{array}$ & $\begin{array}{l}0.0220 \\
(0.017\end{array}$ \\
\hline 1.NPC & $\begin{array}{r}-0.0546 \\
(0.041)\end{array}$ & $\begin{array}{r}-0.0761 \\
(0.050)\end{array}$ & $\begin{array}{r}-0.0227 \\
(0.041)\end{array}$ \\
\hline 1.FDI * $1 . \mathrm{NPC}$ & $\begin{array}{c}-0.0107 * * \\
(0.005)\end{array}$ & $\begin{array}{c}-0.0098^{*} \\
(0.005)\end{array}$ & $\begin{array}{l}-0.0033 \\
(0.008)\end{array}$ \\
\hline 1.CP & $\begin{array}{c}0.0516^{* *} \\
(0.021)\end{array}$ & & \\
\hline 1.CT & & $\begin{array}{c}0.0628^{* *} \\
(0.027)\end{array}$ & \\
\hline 1.CF & & & $\begin{array}{l}0.0202 \\
(0.021)\end{array}$ \\
\hline 1.FDI * $1 . \mathrm{CP}$ & $\begin{array}{c}0.0080^{*} \\
(0.005)\end{array}$ & & \\
\hline 1.FDI * $1 . \mathrm{CT}$ & & $\begin{array}{c}0.0095^{*} \\
(0.005)\end{array}$ & \\
\hline \multirow[t]{2}{*}{ 1.FDI * $1 . \mathrm{CF}$} & & & 0.0043 \\
\hline & & & $(0.004)$ \\
\hline $\mathrm{N}$ & 142 & 147 & 138 \\
\hline M2 & 0.612 & 0.853 & 0.641 \\
\hline Sargan & 131.86 & 126.94 & 141.12 \\
\hline No. Instru. & 78 & 78 & 78 \\
\hline $\mathrm{F}$ & 7959.73 & 16220.13 & 22475.94 \\
\hline
\end{tabular}

Note: all system GMM estimators are one-step estimators. ${ }^{*},{ }^{* *},{ }^{* * *}$ represent significance level at $1 \%, 5 \%$, and $10 \%$ respectively. Numbers in parentheses are robust standard errors. All year dummies are omitted from the result table to save space. 
Notes

1 The author would like to thank Jenny Corbett, Emma Aisbett, Trevor Breusch, Jane Golley, and Ligang Song for helpful comments. Correspondence e-mail: ying.xu@anu.edu.au.

2 Also, Hale and Long (2007)'s review of the empirical evidence of FDI spillovers, productivity impacts of FDI, suggest the results are mixed in China.

3 IMF classification of transition economies is referred to (IMF 2000).

4 The private credit ratio is defined here as the ratio of credits to the private sector to GDP.

5 Securities (bond and stock) markets are still in their early stage of development in China. Equity depth is only 17 percent of GDP, compared to 56 percent in India and 161 percent in Malaysia). Corporate bonds available on the market are just 1 percent of GDP (MGI 2006).

6 Although three policy banks were established in 1994 to free commercial banks from 'direct credit', Wong and Wong (2001) argue as the policy banks lack sufficient branch networks or capital to achieve the task, the state commercial banks continued to engage in policy lending one way or another. Boyreau-Debray (2003) provides statistics to show that the government uses the state-owned banks as a policy instrument to support the state sector. Park and Sehrt (2001) also find evidence that the central government channels banking loans from rich provinces to SOEs of poor provinces for tackling the political concern of regional inequality.

7 In Mankiw et al. (1992) and others, income growth is observed over a frequency of five to ten years so the steady-state values are constructed using average values of each period. However, lack of financial market data confines the study to a total observation period of eight years. So annual growth is studied and the initial values of the determinants are taken as steady-state values.

8 The most recent examples are Guillaumont Jeanneney et al. (2005) and Guariglia and Poncet (2007).

9 In general, taking GDP ratios on a variable does not change its coefficients. In a simple

form, $\ln y=\alpha \ln \left(\frac{W}{G D P}\right)=\alpha \ln W-\alpha \ln G D P$.

When interaction terms are included, coefficients of the variables involved change fundamentally and the coefficients associated with levels cannot be calculated using coefficients of the ratios.

$$
\ln y=\beta \ln \left(\frac{W}{G D P}\right)+\gamma \ln \left(\frac{X}{G D P}\right)+\delta\left[\ln \left(\frac{W}{G D P}\right) \ln \left(\frac{X}{G D P}\right)\right]
$$

10 Price indexes of trade, FDI inflows and financial values are not available in the provincial level. Local GDP deflators are used as proxies. Assumptions associated with this simplification can be found in Bayoumi and Lipworth (1998).

11 The 'dynamic panel bias' (Nickell 1981; Roodman 2006) is essentially an endogeneity problem, i.e. the lagged dependent variable, one of the regressors, is correlated with the error term, which is inherent in the model structure.

12 Hsiao (1986) shows that in an AR(1) model which is equivalent to (2), OLS estimate of is biased upwards in the presence of individual-specific effects. Nickell (1981) suggests Within-group estimate of is biased downward in short panels.

13 For simplicity, the two methodologies are subsequently referred to as Difference GMM and System GMM estimation methodologies. 
$14 x_{i t}$ is strictly exogenous if $E\left[x_{\dot{t}} u_{\dot{b}}\right]=0$ for all $t$ and $S ; x_{\dot{t}}$ is predetermined if $E\left[x_{\dot{t}} u_{\dot{b}}\right] \neq 0$ for $s<t$ but $E\left[x_{\dot{t}} u_{\dot{b}}\right]=0$ for all $s \geq t ; x_{\dot{t}}$ is endogenous if $E\left[x_{\dot{t}} u_{\dot{b}}\right] \neq 0$ for $s \leq t$ but $E\left[x_{\dot{t}} u_{\dot{b}}\right]=0$ for all $s>t$.

15 The initial condition are that the panel level effects the panel level effects are uncorrelated with the first difference of the first observation of the dependent variable: $E\left[\eta_{i} \Delta y_{i 2}\right]=0$ for $i=1, \ldots, N$. Bond et al. (2001) suggest that the initial conditions are potentially consistent with standard growth frameworks.

16 A complete instrument matrix

$$
Z_{i}=\left(\begin{array}{ccccc}
Z_{\dot{d}} & 0 & D_{i} & 0 & \mathbf{I}_{i}^{d} \\
0 & Z_{L} & 0 & L_{i} & \mathbf{I}_{i}^{L}
\end{array}\right)
$$

$Z_{\boldsymbol{d}}$ is the matrix of GMM-type instruments created for the differenced equations, $Z_{\boldsymbol{L}}$ is the matrix of GMM-type instruments for the level equations, $D_{i}$ is the standard instruments for the difference equations, $L_{i}$ is the matrix of instruments for the level equations, $\mathbf{I}_{i}^{d}$ is the standard instruments for the differenced errors and $\mathbf{I}_{i}^{L}$ is the standard instruments for the level errors.

17 How orthogonal deviations can minimize data loss is explained in Roodman (2006; 2007).

18 Another option for small private enterprises is to surrender partial or whole control for the foreign capital to form joint-ventures or wholly-owned foreign enterprises. In both cases, they are no longer identified as PRVs.

19 Financial institutions include banks, saving deposit agencies of postal offices, housing saving banks, urban and rural credit cooperatives, urban credit banks, financial trust investment agencies and finance companies.

20 The computer package can produce both one-step and two-step estimators using difference/system GMM estimation methods. One-step GMM estimators are based on the assumption of homoscedastic error terms, while two-step estimators have no assumption on the error term and often considered as asymptotically more efficient. However, Bond et al. (2001) suggests that the asymptotic standard errors associated with the two-step GMM estimators can be seriously biased downwards in finite samples and thus form an unreliable guide for inference. Given the dataset employed in this study is a small finite sample, onestep estimators are reported.

21 Another main destination of bank credit at the local level is large infrastructure projects, which however generates more of political credits for local politician rather than local economy (Yu 2009).

22 Regressions without the variable of total credits are examined as well, but there are no significant results generated for all three sub-groups of private credits. It is suspected that the private credit variable may pick up the negative effects of SOE credits, which reduce any positive effects private credits could have. 
Asia Pacific Economic Papers

\section{Previous Asia Pacific Economic Papers}

382 A Tale of Pork Prices: Evasion and Attenuation of a Japanese Tariff Kazuki Onji, 2009

381 Are the East Asian Currencies Still Misaligned? An Analysis Based on Absolute ppp-Income Relationship using Panel Data

Taizo Motonishi, 2009

380 Is Foreign Aid a Vanguard of Foreign Direct Investment? A Gravity-Equation Approach Hidemi Kimura and Yasuyuki Todo, 2009

379 Rain, Elections and Money: The Impact of Voter Turnout on Distributive Policy Outcomes in Japan Yusaku Horiuchi and Jun Saito, 2009

378 Japanese FDI in China: determinants and performance Shiro Armstrong, 2009

377 Expansion Abroad and Jobs at Home: Evidence from Japanese Multinational Enterprises Nobuaki Yamashita and Kyoji Fukao, 2009

376 Should Australia Encourage Developing Countries to Adopt Competition Laws? Henry Ergas, 2008

375 Will New Trends in Foreign Direct Investment Change the Structure of Intra-industry Trade between China and Japan?

Tao Tao, 2008

374 Competition Policy in ASEAN: Case studies

Johannah Branson, 2008

373 Can the New Antimonopoly Act Change the Japanese Business Community? The 2005 Amendment to Antimonopoly Act and Corporate Compliance.

Kazukiyo Onishi, 2008

372 Immunising future trade against protectionists: preventing the emergence of more sensitive sectors Andrew Elek, 2008

371 Tax law asymmetries and income shifting: evidence from Japanese Capital KEIRETSU Kazuki Onji and David Vera, 2008

370 The response of firms to eligibility thresholds: evidence from the Japanese value-added tax Kazuki Onji, 2008

369 China and East Asian Energy: Prospects and Issues Vol. 1 \& 11

Peter Drysdale, Kejun Jiang and Dominic Meagher, 2008

368 Measuring trade and trade potential

Shiro Armstrong, 2007

367 APEC and infectious disease: meeting the challenge Joel Gilbourd, 2007

366 The flow of funds through a government - A case study on Japan Jun Ikeda, 2007

365 The puzzle of small farming in Japan roshibisa Godo, 2007

364 How should one evaluate fiscal conditions? A study based on the comparison between Japan and Australia Jun Ikeda, 2007

363 Political institutions and distributive politics in Japan: getting along with the opposition Yusaku Horiuchi, 2007

362 Negotiating the Australia-Japan basic treaty of friendship and cooperation: reflections and afterthoughts Garry Woodard, Moreen Dee and Max Suich, 2007 
Annual subscription rate for up to eight issues:

Individuals A $\$ 65.00$ (includes GST) A \$60 (overseas)

Institutions A\$110.00 (includes GST) A \$100 (overseas)

\title{
Cost for single issues:
}

\author{
A $\$ 16.50$ (includes GST) A $\$ 15.00$ (overseas) \\ A $\$ 10.00$ (Students) \\ No postage required within Australia
}

\section{Available from:}

Centre Administrator

Australia-Japan Research Centre

Crawford School of Economics and Management

ANU College of Asia and the Pacific

The Australian National University

Canberra ACT 0200, Australia

Facsimile: (61 2) 61250767

Telephone: (61 2) 61253780

Email: ajrc@anu.edu.au

URL: http:/www.crawford.anu.edu.au 